\title{
Extracellular ATP activates nuclear translocation of ERK1/2 leading to the induction of matrix metalloproteinases expression in human endometrial stromal cells
}

\author{
Shu-Ju Chang', Tao-Yeuan Wang ${ }^{2}$, Yi-Hsuan Lee ${ }^{3}$ and Chen-Jei Tai ${ }^{4}$ \\ ${ }^{1}$ Graduate Institute of Medical Sciences, College of Medicine, Taipei Medical University, Taipei, Taiwan \\ ${ }^{2}$ Department of Pathology, Mackay Memorial Hospital and Mackay Medicine, Nursing and Management College, Taipei, Taiwan ROC \\ ${ }^{3}$ Department of Physiology and Department of Traditional Chinese Medicine, Taipei Medical University Hospital, Taipei, Taiwan ROC \\ ${ }^{4}$ Department of Obstetrics and Gynecology, Taipei Medical University, 252 Wu-Xing Street, Xin-Yi District, Taipei, 110, Taiwan ROC \\ (Requests for offprints should be addressed to C-J Tai; Email: chenjtai@tmu.edu.tw)
}

\begin{abstract}
ATP has been shown to activate the mitogen-activated protein kinase (MAPK) signaling pathway in various systems. However, little is known about the signaling events and the effects in human endometrial stromal cells (hESCs). The present study examined the effect of ATP on activating MAPKs and its subsequent events in hESCs. This study demonstrated the expression of the $\mathrm{P}_{2 \mathrm{U}} / \mathrm{P}_{2} \mathrm{Y}_{2}$ receptor in hESCs by reverse transcription-PCR (RT-PCR). A PCR product with a sequence identical to the reported $599 \mathrm{bp}$ $\mathrm{P}_{2 \mathrm{U}} / \mathrm{P} 2 \mathrm{Y}_{2}$ receptor cDNA was obtained. Western blot analysis, using a monoclonal antibody against the phosphorylated forms of ERK1/2, demonstrated that ATP activated MAPK in a dose- and time-dependent manner. Confocal microscopy showed an evident nuclear translocation of phosphorylated ERKs after $10 \mu \mathrm{M}$ ATP treatment, but this effect was blocked by PD98059. To study the gene(s) induced
\end{abstract}

by exogenous ATP, mRNA was extracted from hESCs in the presence or absence of $10 \mu \mathrm{M}$ ATP. The gene array for 96 genes associated with members of human matrix metalloproteinases (MMPs) and adhesion molecules revealed that the expression of $M M P-2,-3,-10$, and -24 genes was increased and the effect was attenuated by PD98059. Furthermore the effects of ATP on the expression of MMP genes were confirmed by semiquantitative RT-PCR. To our knowledge, this is the first demonstration of the ATP-induced nuclear translocation of phospho-ERK1/2 that mediates $M M P s$ gene expression in human endometrial cells. These results support the notion that the ERK1/2 signaling pathway is involved in mediating ATP actions in the human reproductive system.

Journal of Endocrinology (2007) 193, 393-404

\section{Introduction}

The female reproductive system is innervated by autonomic nerves and supplied by blood vessels (Willson et al. 1965, Owman et al. 1967). ATP is released from cells such as platelets and co-released with neurotransmitter granules from autonomic nerve endings by exocytosis (Gordon 1986). Extracellular ATP binds to a G-protein-coupled P2 purinoceptor and induces intracellular signaling transduction (Berridge 1984, Gordon 1986). Thereafter, ATP may participate in various types of physiological responses, including intracellular signaling transduction, secretion, cell proliferation, platelet aggregation, and neurotransmission (el-Moatassim et al. 1992, Burnstock \& Knight 2004).

The distribution of the autonomic nerves and blood vessels in the female reproductive system leads us to speculate that the released ATP may play a role in regulating endometrial functions such as implantation, cell proliferation, and cell

differentiation. Our previous data demonstrated that extracellular ATP, through a transmembrane purinergic receptor (Tai et al. 2000), plays a crucial role in regulating ovarian functioning by activating the intracellular signaling pathway and modulating human chorionic gonadotropin action (Tai et al. 2001a,b). However, the role of ATP in other human reproduction-related cells, such as human endometrial stromal cells (hESCs), remains to be determined. The present study was designed to examine the presence of the purinergic receptor and the effects of exogenous ATP on the intracellular mitogen-activated protein kinases (MAPKs) and gene expression in hESCs.

MAPKs are a group of serine-threonine kinases involved in relaying extracellular stimuli into intracellular signals (Brunet \& Pouyssegur 1997). When activated, ERK1 and ERK2 (also known as $\mathrm{p} 42^{\text {mapk }}$ and $\mathrm{p} 44^{\mathrm{mapk}}$ respectively) may be imported into the nucleus and phosphorylate a variety of substrates, which have been implicated in the control of cell 
proliferation, differentiation, and gene expression (Brunet et al. 1999, Kim-Kaneyama et al. 2000). The present study was designed to examine the action of ATP on nuclear translocation of activated ERK1/2 in hESCs.

Tissue remodeling involving endometrial extracellular matrix (ECM) turnover plays a major role in placenta invasion, regulated by the combined action of matrix metalloproteinases (MMPs) and the tissue inhibitors of MMPs (TIMPs). The MMPs are a family of extracellular endopeptidases that selectively degrade components of the ECM (Henriet et al. 2002). Based on substrate specificity, the MMPs are grouped into: 1) collagenases, which regulate interstitial ECM turnover by degrading interstitial collagens types I-III via a specific cleavage that denatures the helical structure of these fibrillar collagens; 2) gelatinases, which degrade basement membrane collagens IV and V as well as denatured interstitial collagens (gelatins); 3) stromelysins, which degrade such diverse ECM proteins as proteoglycans, glycoproteins, fibronectin, and laminin, and can cleave the globular domain of interstitial (type III) and basement membrane collagen types IV and V; and 4) membrane-type MMPs, which digest a number of ECM molecules. MT1MMP has collagenolytic activity on types I-III collagens (Dong et al. 2002). One of the striking features of the MMPs is that many of those genes are 'inducible'. The activators include growth factors, cytokines, and chemical agents. The enhanced MMP gene expression may be downregulated by suppressive factors such as TIMPs (Goffin et al. 2003, Visse \& Nagase 2003). In the present study, we examined the effect of ATP on the expression of MMP genes in hESCs.

\section{Materials and Methods}

\section{Reagents and materials}

ATP was obtained from Sigma Chemical Co. PD98059, a MEK inhibitor, was purchased from Cell Signaling Technology, Inc. (Danvers, MA, USA). Dulbecco's Modified Eagle's Medium (DMEM), penicillin-streptomycin, and fetal bovine serum (FBS) were obtained from GIBCO-BRL. PD98059 was dissolved in dimethyl sulfoxide, as suggested by the manufacturer. Phospho-p44/42 MAPK (Thr202/Tyr204) E10 monoclonal antibody (catalog no. 9106), and p44/42 MAPK polyclonal antibody (catalog no. 9102) were purchased from Cell Signaling Technology Inc. Normal donkey serum, biotin-SP-conjugated AffiniPure (goat antirabbit $\operatorname{IgG}(\mathrm{H}+\mathrm{L})$ or goat anti-mouse $\operatorname{IgG}(\mathrm{H}+\mathrm{L}))$, Cy2conjugated streptavidin and $\mathrm{Cy} 3$-conjugated streptavidin were purchased from Jackson ImmunoResearch Laboratories, Inc. (West Grove, PA, USA). TOTO-3 iodide was bought from Molecular Probes, Inc. (Eugene, OR, USA). BSA and glycerol were obtained from Sigma Chemical Co. GEArray was purchased from SuperArray Bioscience Corporation (Frederick, MD, USA; www.superarray.com; GEArray Q Series Human ECM \& Adhesion Molecules Gene Array).
Access RT-PCR System was obtained from Promega Corporation (Cat. no. A1250; www.promega.com).

\section{Tissue collection and hESCs cultures}

Samples of proliferative phase endometrium were obtained from 30 cyclic women (ages 27-48 years) undergoing hysterectomy who had no history of malignancy. Patient informed consent was obtained from the patients prior to tissue collection. The use of human endometrium was approved by the Clinical Screening Committee for Research and Other Studies Involving Human Subjects of Taipei Medical University Hospital.

Isolation of hESCs was performed following the protocol reported by Shiokawa et al. (1996) and Gargett et al. (2001). Briefly, the $100 \mathrm{mg}$ endometrium was minced and subjected to $0 \cdot 1 \%$ collagenase (type IV, Sigma Chemical Co.) and $0 \cdot 1 \%$ hyaluronidase (type I-S, Sigma Chemical Co.), and was digested in a shaking water bath at $37^{\circ} \mathrm{C}$ for $1 \mathrm{~h}$. The cells were pelleted by centrifugation at $800 \mathrm{~g}$ for $10 \mathrm{~min}$ at room temperature. The cell pellet was resuspended in DMEM. The endometrial cells were collected in a $50 \mathrm{ml}$ tube after being passed through a nylon sieve $(100 \mu \mathrm{M})$ to remove the large cell mass, and collected cells were passed through a smaller nylon sieve $(40 \mu \mathrm{M})$ to separate stromal cells from epithelial cells. The cells were cultured in DMEM supplemented with $10 \% \mathrm{FBS}$ and incubated at $37^{\circ} \mathrm{C}$ in a water-saturated atmosphere of $5 \% \mathrm{CO}_{2}$ in air. The purity of the stromal cell cultures was determined by immunostaining for vimentin and cytokeratin.

\section{Treatments}

Human ESCs were incubated in a serum-free medium for $4 \mathrm{~h}$ prior to treatment. To examine the dose-response relationship, hESCs were treated with increasing concentrations of ATP $(100 \mathrm{nM}, 1 \mu \mathrm{M}, 10 \mu \mathrm{M}$, or $100 \mu \mathrm{M})$ for $5 \mathrm{~min}$. For timecourse experiments, hESCs were treated with $10 \mu \mathrm{M}$ ATP for 1 , 5,10 , or $20 \mathrm{~min}$. To study the action on the expression of genes of the MMPs induced by ATP, hESCs were treated with $10 \mu \mathrm{M}$ ATP for $24 \mathrm{~h}$, and the mRNA was extracted.

\section{Total RNA isolation}

Total RNA was isolated using an RNeasy Mini Kit (Qiagen $\mathrm{GmbH}$ ). Briefly, cells were disrupted in a buffer containing guanidine isothiocyanate and homogenized following the manufacturer's protocol. Ethanol was then added to the lysate, creating conditions that promote the selective binding of RNA to the RNeasy silica-gel membrane. The sample was then applied to the RNeasy mini column. Total RNA was bound to the membrane, contaminants were efficiently washed away, and high-quality RNA was eluted in RNasefree water. The RNA concentration was determined based on absorbance at $260 \mathrm{~nm}$. 


\section{RT-PCR}

One microgram of total RNA obtained from hESCs was reverse transcribed into cDNA using a First Strand cDNA Synthesis Kit (Pharmacia Biotech, Morgan, Canada). One set of oligonucleotide primers $\left(5^{\prime}\right.$ - CCTGGAATGCGTCCACCA- CATAT- $3^{\prime}$ and $5^{\prime}$ - GACGTGGAATGGCAGGAAGCAGA - $3^{\prime}$ ), based on the published human $\mathrm{P}_{2 \mathrm{U}} / \mathrm{P}_{2} \mathrm{Y}_{2}$ receptor sequence (Parr et al. 1994, Burnstock \& Knight 2004) was designed for PCR to amplify the $\mathrm{P}_{2 \mathrm{U}} / \mathrm{P} 2 \mathrm{Y}_{2}$ from hESCs. PCRs were performed in the presence of $10 \mathrm{mM}$ Tris- $\mathrm{HCl}(\mathrm{pH} 8 \cdot 3), 50 \mathrm{mM} \mathrm{KCl}$, $1.5 \mathrm{mM} \mathrm{MgCl} 2,400 \mu \mathrm{m}$ dNTPs, $0.25 \mathrm{U}$ Taq DNA polymerase, $2 \mu \mathrm{M}$ primers, and $1 \mu \mathrm{l}$ cDNA template per $25 \mu \mathrm{l}$ reaction. Amplification was carried out for 33 cycles with denaturation at $94{ }^{\circ} \mathrm{C}$ for $60 \mathrm{~s}$, annealing at $64{ }^{\circ} \mathrm{C}$ for $35 \mathrm{~s}$ and extension at $72{ }^{\circ} \mathrm{C}$ for $90 \mathrm{~s}$, and a final extension at $72{ }^{\circ} \mathrm{C}$ for $15 \mathrm{~min}$. Ten microlitres of the PCR products of $\mathrm{P}_{2 \mathrm{U}} / \mathrm{P} 2 \mathrm{Y}_{2}$ receptor were fractionated in a $1 \%$ agarose gel stained with ethidium bromide. The expected PCR products (599 bp) were isolated from the gel, cloned using a TA cloning kit (Invitrogen), and sequenced by the dideoxy chain termination method using a T7 DNA polymerase sequencing kit (Pharmacia Biotech). The sequence of the cDNA was sent to the GenBank at the National Center for Biotechnology Information (NCBI) through the internet (www.ncbi.nlm.nih.gov), in order to compare the identity with published human $\mathrm{P}_{2 \mathrm{U}} / \mathrm{P}_{2} \mathrm{Y}_{2}$ receptor.

To examine the dose-effect of ATP on MMPs mRNA, hESCs were treated with increasing concentrations of ATP $(0 \cdot 1 \mu \mathrm{M}$, $10 \mu \mathrm{M}$, or $100 \mu \mathrm{M})$ for $24 \mathrm{~h}$, and the mRNA was extracted. One microgram total RNA was reverse transcribed into first strain cDNA using the Access RT-PCR System according to the manufacturer's instructions (Promega). Primers for human MMP-2 (5'-AGATCTTCTTCTTCA- AGGACCGGTT-3' and $5^{\prime}$-GGCTGGTCAGTGGCTTGGGGTA- $3^{\prime}$ ) were designed based on published sequences (Goffin et al. 2003). Primers for human MMP-3 (5'-GAAATTCCA- TGGAGCCAGGG-3' and $5^{\prime}$-AGTGTGACTCGAGTCACAGC- $3^{\prime}$ ) and primers for human MMP-10 (5'-GCAGCGGACAAATACTGGAGA- $3^{\prime}$ and $5^{\prime}$-TATGTGTGT- CACCATCCTGGC-3 ${ }^{\prime}$ ) were designed based on published sequences (Kim et al. 2001). Primers for human MMP-24 (5'CACAAGGCCACT- CCCTACAC- $3^{\prime}$ and $5^{\prime}$-TAGGTCT TG- CCCACAGGTTC-3') were designed based on published sequences (Jung et al. 2003). The one-step RT-PCR conditions were $45{ }^{\circ} \mathrm{C}$ for $45 \mathrm{~min}$ to synthesize the first strand of cDNA, $94^{\circ} \mathrm{C}$ for $2 \mathrm{~min}$ to denature the template and to synthesize the second strand and DNA amplification. Amplification of MMP-2 was carried out for 27 cycles with denaturation at $94^{\circ} \mathrm{C}$ for $15 \mathrm{~s}$, annealing at $68.5^{\circ} \mathrm{C}$ for $20 \mathrm{~s}$, and extension at $72{ }^{\circ} \mathrm{C}$ for $10 \mathrm{~s}$, and a final extension at $72{ }^{\circ} \mathrm{C}$ for $2 \mathrm{~min}$. Amplification of MMP-3 was carried out for 35 cycles with denaturation at $94^{\circ} \mathrm{C}$ for $40 \mathrm{~s}$, annealing at $56 \cdot 1{ }^{\circ} \mathrm{C}$ for $90 \mathrm{~s}$, and extension at $72{ }^{\circ} \mathrm{C}$ for $2 \mathrm{~min}$, and a final extension at $72^{\circ} \mathrm{C}$ for $5 \mathrm{~min}$. Amplification of MMP-10 was carried out for 30 cycles with denaturation at $94^{\circ} \mathrm{C}$ for $40 \mathrm{~s}$, annealing at $57.7{ }^{\circ} \mathrm{C}$ for $90 \mathrm{~s}$, and extension at $72{ }^{\circ} \mathrm{C}$ for $2 \mathrm{~min}$, and a final extension at $72{ }^{\circ} \mathrm{C}$ for $5 \mathrm{~min}$. Amplification of
MMP-24 was carried out for 45 cycles with denaturation at $95{ }^{\circ} \mathrm{C}$ for $1 \mathrm{~s}$, annealing at $66.4{ }^{\circ} \mathrm{C}$ for $5 \mathrm{~s}$, and extension at $72{ }^{\circ} \mathrm{C}$ for $15 \mathrm{~s}$, and a final extension at $72^{\circ} \mathrm{C}$ for $7 \mathrm{~min}$. The PCR annealing temperature was selected by the Mastercycler gradient 5331 machine (Eppendorf AG, Hamburg, Germany). In addition, GAPDH of the individual sample was used as the internal control. Primers for GAPDH (5'-ATGTTCGTCATGGGT- GTGAACCA- $3^{\prime}$ and $5^{\prime}$-TGGCAGGTT- TTTCTAGACGGCAG-3') were designed based on published sequences (Tokunaga et al. 1987). Amplification was carried out for 18 cycles with denaturation at $94{ }^{\circ} \mathrm{C}$ for $60 \mathrm{~s}$, annealing at $57 \cdot 1{ }^{\circ} \mathrm{C}$ for $35 \mathrm{~s}$, and extension at $72{ }^{\circ} \mathrm{C}$ for $90 \mathrm{~s}$, and a final extension at $72{ }^{\circ} \mathrm{C}$ for $15 \mathrm{~min}$. Eight microliters of PCR products of MMP-2, $-3,-10$, and -24 were fractionated in a $3 \%$ agarose gel and stained with ethidium bromide for $30 \mathrm{~min}$ and visualized under a u.v. transilluminator (E-BOX 1000, Vilber Lourmat, Marnela-Vallee, France). A 100 bp DNA ladder (Promega) was used as a molecular weight marker. The autographs were quantified with E-CAPT software (Vilber Lourmat).

\section{Western blot analysis}

The hESCs were washed with ice-cold PBS and lysed with $100 \mu \mathrm{l}$ cell lysis buffer (RIPA, $150 \mathrm{mM} \mathrm{NaCl}, 50 \mathrm{mM}$ Tris$\mathrm{HCl}(\mathrm{pH} 7 \cdot 5), 1 \%$ Nonidet $\mathrm{P}-40,0 \cdot 5 \%$ deoxycholate, $0 \cdot 1 \%$ SDS, $1.0 \mathrm{mM}$ PMSF, $10 \mu \mathrm{g} / \mathrm{ml}$ leupeptin, and $100 \mu \mathrm{g} / \mathrm{ml}$ aprotinin) at $4{ }^{\circ} \mathrm{C}$ for $30 \mathrm{~min}$. The cell lysate was centrifuged at $10000 \mathrm{~g}$ for $5 \mathrm{~min}$, and the supernatant was collected for western blot analysis. The amount of protein was quantified using a Bio-Rad protein assay kit (Bio-Rad Laboratories), following the manufacturer's protocol. Aliquots $(30 \mu \mathrm{g})$ were subjected to $10 \%$ SDS-PAGE under reducing conditions as previously described (Laemmli 1970). The proteins were electrophoretically transferred from the gels onto nitrocellulose membranes (Amersham Pharmacia Biotech), following the procedures of Towbin et al. (1979). These nitrocellulose membranes were probed with a mouse monoclonal antibody directed against the phosphorylated forms of ERK1 and ERK2 (P-MAPK, $\mathrm{p} 42^{\text {mapk }}$ and $\mathrm{p} 44^{\mathrm{mapk}}$ respectively) at $4{ }^{\circ} \mathrm{C}$ for $16 \mathrm{~h}$. Alternatively, membranes were probed with a rabbit polyclonal antibody for $\mathrm{p} 42 / \mathrm{p} 44$ MAPK, which detects total MAPK (T-MAPK) levels (Cell Signaling Technology Inc.). After washing, the membranes were incubated with HRP-conjugated goat anti-mouse secondary antibody, and the signal was visualized using an ECL system (Amersham Pharmacia Biotech) followed by exposure to X-ray film. The autographs were scanned and quantified with Image Pro Plus software (Media Cybernetics, Inc., Silver Spring, MA, USA).

\section{MAP kinase assay}

To measure MAP kinase activity, a nonradioactive method was used (p44/42 MAP Kinase Assay Kit, Cell Signaling Technology Inc). Briefly, active MAP kinase of cell lysate $(200 \mu \mathrm{g})$ from hESCs treated with $10 \mu \mathrm{M}$ ATP for 10 min was selectively immunoprecipitated with an immobilized monoclonal 
antibody to phospho-p44/42 MAP kinase. For the positive control, active MAP kinase (provided by the manufacturer) was added to the control cell extract. The resulting precipitate was incubated with an Elk-1 fusion protein in the presence of ATP, which allowed immunoprecipitated active MAPK to phosphorylate Elk-1. Phosphorylated Elk-1 was detected by western blot using a phospho-Elk-1 antibody.

\section{Confocal fluorescence microscopy}

Human ESCs were plated onto glass coverslips and grown to $40 \%$ confluence at $37^{\circ} \mathrm{C}$ in humidified air with $5 \% \mathrm{CO}_{2}$. Cells were treated with $10 \mu \mathrm{M}$ ATP for $10 \mathrm{~min}$ in the absence or presence of PD98059 (pretreated for $30 \mathrm{~min}$ before ATP exposure), fixed in $4 \%$ paraformaldehyde in PBS for $10 \mathrm{~min}$ at room temperature and permeabilized with $1 \%$ Nonidet P-40 in PBS for $20 \mathrm{~min}$. Nonspecific staining was blocked with $10 \%$ normal donkey serum. The cells were incubated with the primary antibody, phosphorylated ERK1/2 or total ERK1/2, diluted 1: 400 with $2 \%$ BSA in PBS overnight at $4{ }^{\circ} \mathrm{C}$. After three washes in PBS containing $0 \cdot 1$ Tween-20, the cells were incubated with goat anti-mouse $\operatorname{IgG}(\mathrm{H}+\mathrm{L})$ or goat anti-rabbit $\operatorname{IgG}(\mathrm{H}+\mathrm{L})$ for $60 \mathrm{~min}$ at room temperature, and washed as above. The cells were then incubated with Cy2-conjugated streptavidin or Cy3-conjugated streptavidin, diluted in the ratio of 1: 3000 in PBS, for $30 \mathrm{~min}$ at room temperature. After the antibody incubations, the coverslips were washed in PBS, and nuclei were stained with TOTO-3 iodide, diluted in PBS, for $20 \mathrm{~min}$ at room temperature. Coverslips were mounted onto slides with glycerol and viewed on a confocal laser scanning microscopy (Model FV500, Olympus, Tokyo, Japan) using the $40 \times$ objective. Images were acquired and quantified using FLUOVIEW software (version 4.0, Olympus).

\section{Gene array analysis}

Human ESCs were treated with $10 \mu \mathrm{M}$ ATP for $24 \mathrm{~h}$ in the absence or presence of PD98059 (pretreated for $30 \mathrm{~min}$ before ATP exposure) prior to RNA extraction. Biotinylated cDNA probes were synthesized from $5 \mu \mathrm{g}$ total RNA of ATP-treated or control samples using SuperArray's proprietary GEAprimer mix as reverse transcriptase primers and hybridized to the GEArray Q Series membrane spotted with 96 gene-specific cDNA fragments, following the manufacturer's instructions (SuperArray Bioscience). Briefly, total RNA was used as a template for the synthesis of cDNA probes with dNTP mix containing biotin-16-dUTP incorporation using the RT-labeling Kit (SuperArray,

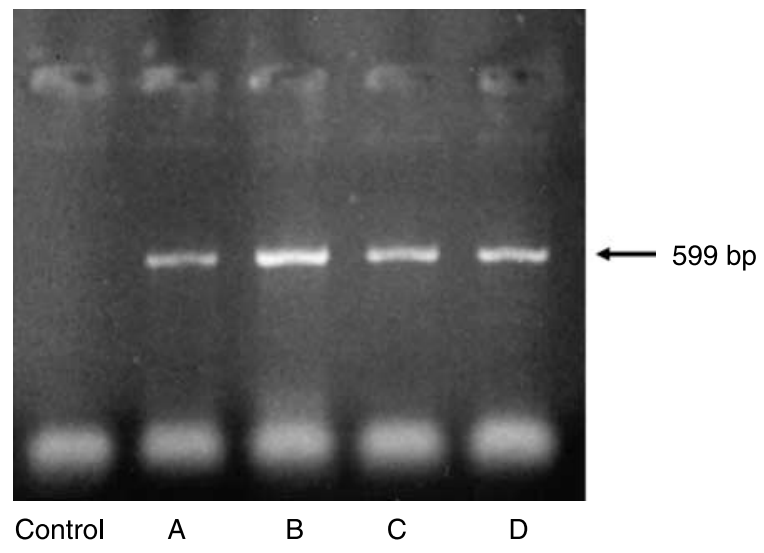

Figure 1 Ethidium bromide-stained DNA gels showing the PCR products from three patients. Columns A-C are PCR products of endometrial stromal cells. Column D represents as positive control obtained from human granulosa luteal cells. One microgram total mRNA of hESCs from each patient was reverse transcribed into cDNA, and aliquots were amplified using PCR. A 599 bp product was obtained. The control did not have first strain cDNA in the PCR.

Bioscience). Annealing of RNA with primers was performed in a preheated heat block at $70{ }^{\circ} \mathrm{C}$ for $3 \mathrm{~min}$. Samples were cooled to $42{ }^{\circ} \mathrm{C}$, and kept at $42{ }^{\circ} \mathrm{C}$ for $2 \mathrm{~min}$ before labeling with biotin-16-dUTP. For cDNA probe synthesis, each RNA sample $(5 \mu \mathrm{g})$ was combined with a primer mix and with reverse transcriptase, RNase inhibitor, and a dNTP mix with biotin-16-dUTP and incubated at $42{ }^{\circ} \mathrm{C}$ for $90 \mathrm{~min}$. The GEArray membrane spotted with 96 gene-specific cDNA fragments was moistened with deionized $\mathrm{H}_{2} \mathrm{O}$, and was prehybridized with GEAhyb hybridizational solution containing heat-denatured sheared salmon sperm DNA at $60^{\circ} \mathrm{C}$ for 1 to $2 \mathrm{~h}$. The membrane was incubated with the denatured cDNA probe overnight with continuous agitation at $60^{\circ} \mathrm{C}$, then washed twice with prewarmed $2 \times$ SSC containing $1 \%$ SDS for $20 \mathrm{~min}$ at $60{ }^{\circ} \mathrm{C}$, and twice with pre-warmed $0.1 \times$ SSC containing $0.5 \%$ SDS for $20 \mathrm{~min}$ at $60^{\circ} \mathrm{C}$. After blocking with GEAblocking solution, the membrane was incubated with alkaline phosphatase-conjugated streptavidin, washed with washing buffer, incubated with CDP-Star, a chemiluminescent substrate, and exposed to X-ray film. Each GEArray membrane was spotted with a negative control of PUC18 DNA as well as two positive control genes, $\beta$-actin and GAPDH. The relative abundance of a particular transcript was estimated by comparing its signal intensity to the signal derived from GAPDH. Images of the membranes were recorded on X-ray film and the intensity of the array of

Figure 2. (A) The dose-response of ATP on MAPK activation in hESCs. Human ESCs were treated with increasing concentrations of ATP (0, $0 \cdot 1 \mu \mathrm{M}, 1 \mu \mathrm{M}, 10 \mu \mathrm{M}$ or $100 \mu \mathrm{M}$ ) for $5 \mathrm{~min}$ as described in Materials and Methods. (B). The time course of ATP on MAPK activation in hESCs. Human ESCs were treated with $10 \mu \mathrm{M}$ ATP for $0,1,5,10$ or $20 \mathrm{~min}$, as described in Materials and Methods. The MAPKs were detected by western blot analysis. The data are shown as the relative ratio to basal levels. Values are presented as the mean \pm s.E.M. of three different patients. Differences were considered significant at $* P<0 \cdot 05$. 
A
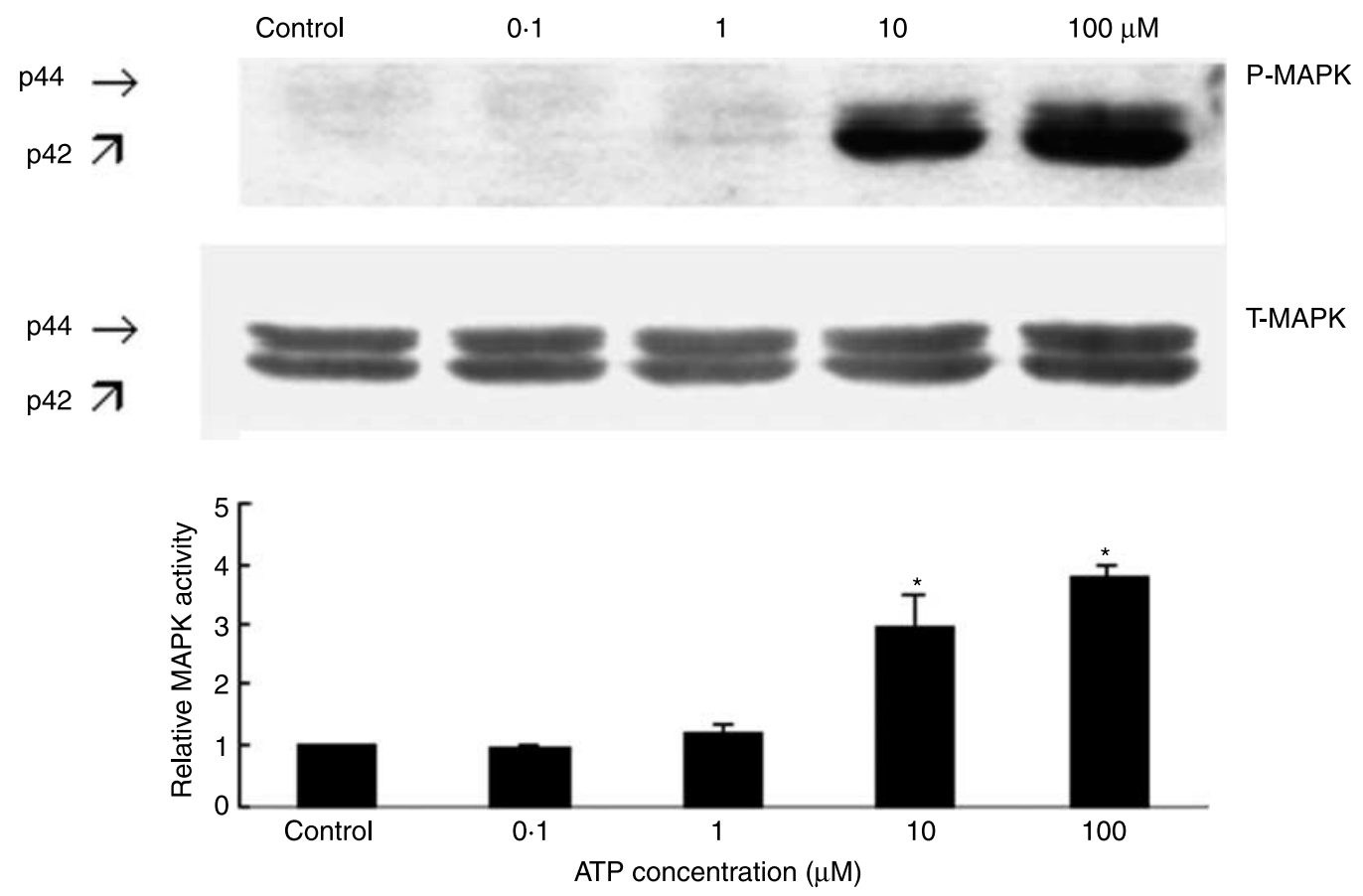

B
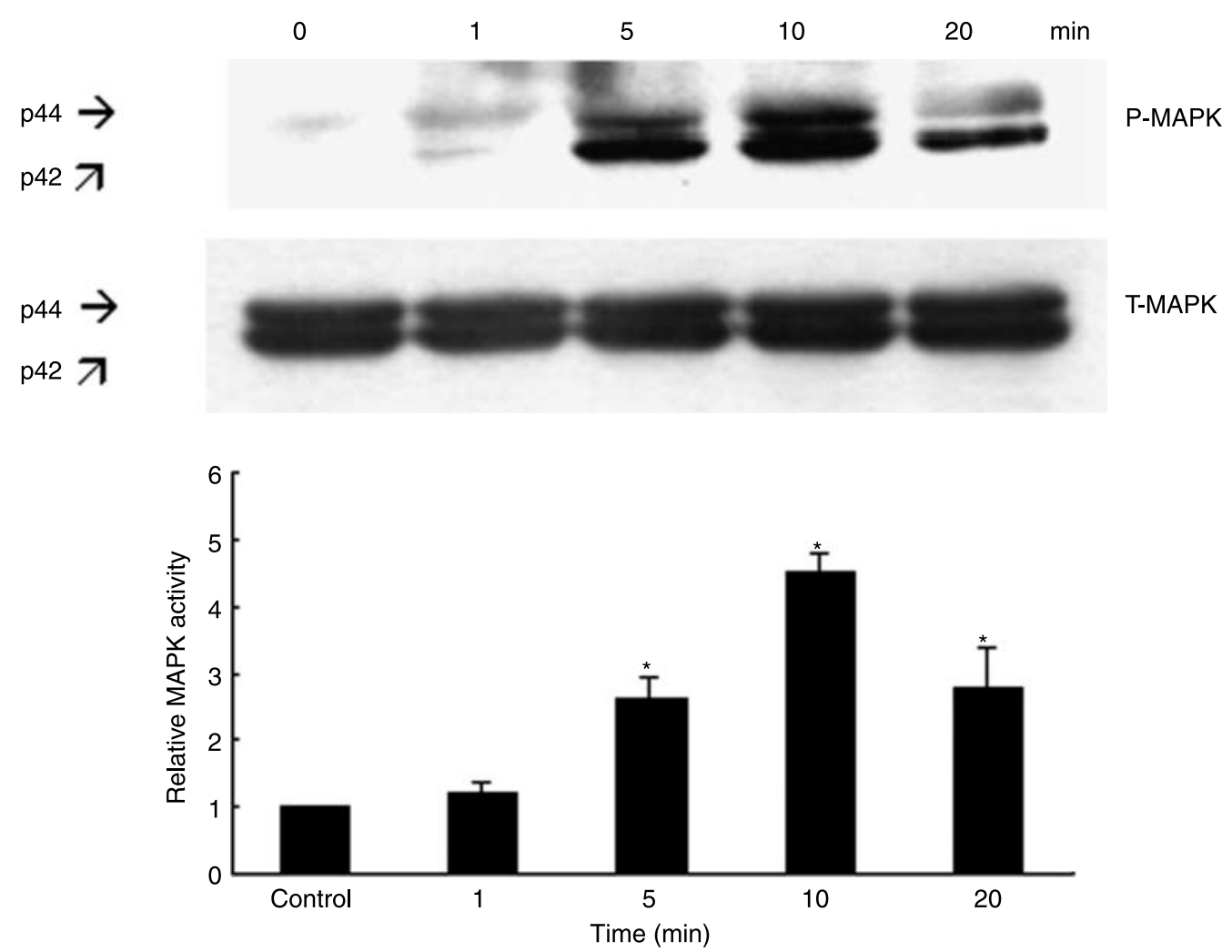

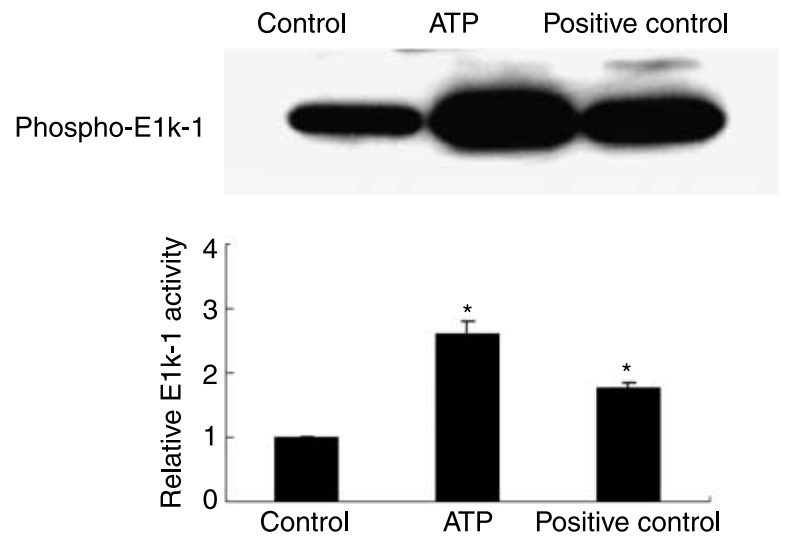

Figure 3 MAP kinase activity in hESCs measured using a MAP kinase assay kit. Human ESCs were treated with $10 \mu \mathrm{M}$ ATP for $10 \mathrm{~min}$, as described in Materials and Methods. Active p42 MAPK was included as a positive control. Values are presented as the mean \pm s.E.M. of three different patients. Differences were considered significant at $* P<0 \cdot 05$.

spots was converted into Adobe Photoshop as a TIFF file. The signal intensity of the spots was compared using the GEArray Expression Analysis Suite (SuperArray Corp., http://www.superarray.com).

\section{Statistical analysis}

MAPK activity was expressed as a relative ratio of basal levels. Independent replicates of experiments in this study were performed with cells from three different patients. Data were represented as means \pm s.E.M. Statistical analysis was performed by one-way ANOVA followed by Tukey's multiple comparison test. Differences were considered significant at $P<0 \cdot 05$.

\section{Results}

Expression of $P_{2 U} / P 2 Y_{2}$ receptor $m R N A$ in hESCs

The expression of the $\mathrm{P}_{2 \mathrm{U}} / \mathrm{P} 2 \mathrm{Y}_{2}$ receptor $\mathrm{mRNA}$ in hESCs was examined by RT-PCR using one set of primers designed on the basis of the published human $\mathrm{P}_{2 \mathrm{U}} / \mathrm{P} 2 \mathrm{Y}_{2}$ receptor expressed in airway epithelium. An expected 599-bp DNA fragment was observed in ethidium bromide-stained gel from hESCs isolated from three different patients (Fig. 1). No product was obtained from the negative control (without a first strain cDNA template in the PCR). The PCR products from hESCs were subcloned and sequenced. Sequence analysis revealed that the cloned cDNA was identical to nucleotide position 4361034 of the published human $\mathrm{P}_{2 \mathrm{U}} / \mathrm{P} 2 \mathrm{Y}_{2}$ receptor (Parr et al. 1994, Burnstock \& Knight 2004).

\section{Effect of ATP on MAPK activation}

To demonstrate the ability of ATP to activate MAPK, hESCs were treated with increasing concentrations (100 nM$100 \mu \mathrm{M})$ of ATP for $5 \mathrm{~min}$. For time-course analysis, the cells were treated with $10 \mu \mathrm{M}$ ATP for varying time intervals (1-20 min). As shown in Fig. 2A, ATP activated MAPK in hESCs in a dose-dependent manner. A significant effect was observed at $10 \mu \mathrm{M}$ with a maximum effect noted at $100 \mu \mathrm{M}$. ATP was capable of rapidly inducing MAPK activity. A significant effect was seen within $5 \mathrm{~min}$ after treatment, and the activation of MAPK was sustained for at least $15 \mathrm{~min}$. As shown in the study, the effect of ATP reached its maximum at $10 \mathrm{~min}$ (Fig. 2B).

\section{MAP kinase activity}

In vitro MAP kinase activity was detected using a p44/42 MAP kinase assay kit. As shown in Fig. 3, ATP significantly increased MAPK activity to $250 \%$ of the control level.

\section{Subcellular ERK1/2 localization}

As shown in Fig. 4(I)-a, the use of a polyclonal antibody against total ERKs demonstrated that ERK1/2 (nonphosphorylated and phosphorylated) were distributed in the cytoplasm. To observe the baseline level of phosphorylated ERK1/2, cells were fixed in the absence of ATP, and the faint intracellular fluorescence revealed that small amounts of phosphorylated ERK1/2 were located in the cytoplasm (Fig. 4II-a). To examine the distribution of ATP-activated

Figure 4. The distribution of p42/p44 and the effect of ATP on phospho-p42/p44 translocation in hESCs. (I)-a, the distribution of p42/p44 in hESCs. Formaldehyde-fixed cells were incubated with polyclonal anti-p42/p44 MAPK antibody followed by goat anti-rabbit IgG $(\mathrm{H}+\mathrm{L})$ and Cy3-conjugated streptavidin. (I)-b, nuclei of cells in (I)-a were stained with TOTO-3 iodide. (I)-c, the final merged image of (I)-a and (I)-b. (II)-a, the localization of the phospho-p42/p44 in hESCs prior to ATP treatment. Formaldehyde-fixed hESCs, in the absence of ATP, were incubated with monoclonal anti-phospho-p42/p44 antibody followed by goat anti-mouse IgG $(\mathrm{H}+\mathrm{L})$ and Cy2-conjugated streptavidin. (II)-b, nuclei of cells in (II)-a were stained with TOTO-3 iodide. (II)-c, the final merged image of (II)-a and (II)-b. (III)-a, the localization of the activated p42/p44 (phospho-p42/p44) in hESCs. Human ESCs were treated with $10 \mu \mathrm{M}$ ATP for $10 \mathrm{~min}$. Formaldehyde-fixed cells were incubated with monoclonal anti-phospho-p42/p44 antibody followed by goat anti-mouse $\lg \mathrm{G}(\mathrm{H}+\mathrm{L})$ and Cy2-conjugated streptavidin. (III)-b, nuclei of cells in (III)-a were stained with TOTO-3 iodide. (III)-c, the final merged image of (III)-a and (III)-b. (IV)-a, the effect of PD98059 on ATP-induced translocation of the activated p42/p44 in hESCs. Human ESCs were treated with $10 \mu \mathrm{M}$ ATP in the presence of PD98059 for 10 min. Formaldehyde-fixed cells were incubated with monoclonal anti-phospho-p42/p44 antibody followed by goat anti-mouse lgG $(\mathrm{H}+\mathrm{L})$ and $\mathrm{Cy} 2-$ conjugated streptavidin. (IV)-b, nuclei of cells in (IV)-a were stained with TOTO-3 iodide. (IV)-c, the final merged image of (IV)-a and (IV)-b. 


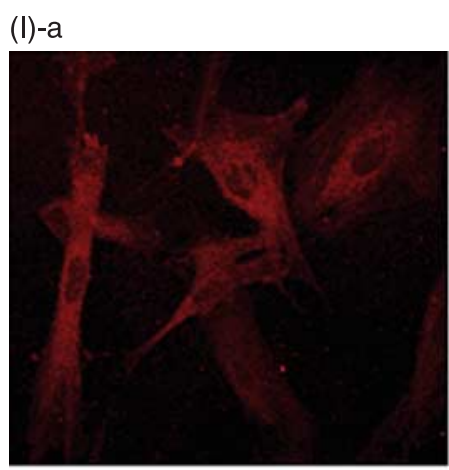

(I)-b

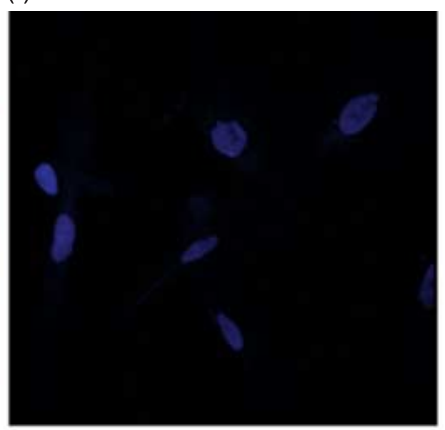

(II)-a

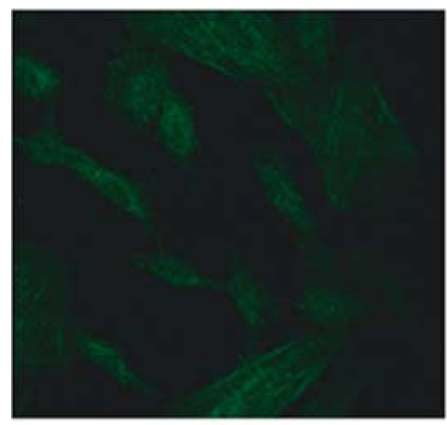

(III)-a

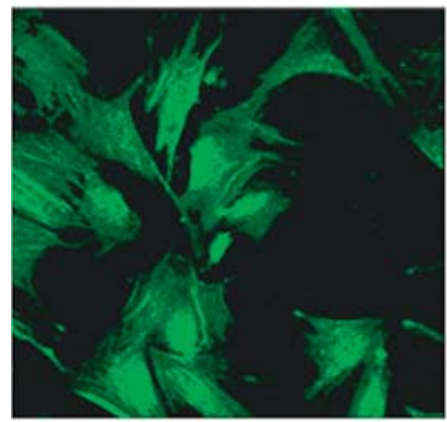

(IV)-a

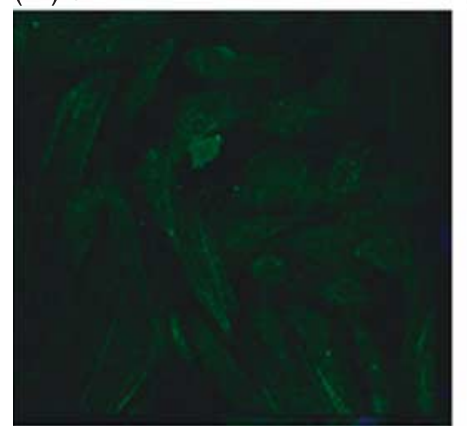

(II)-b

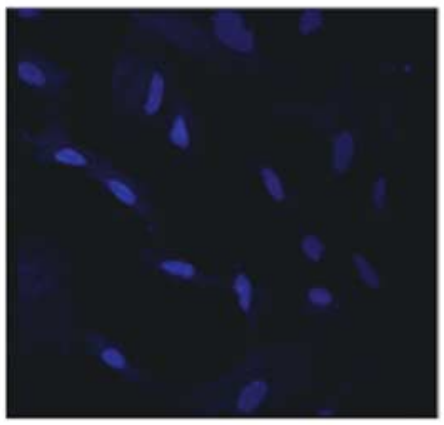

(II)-C

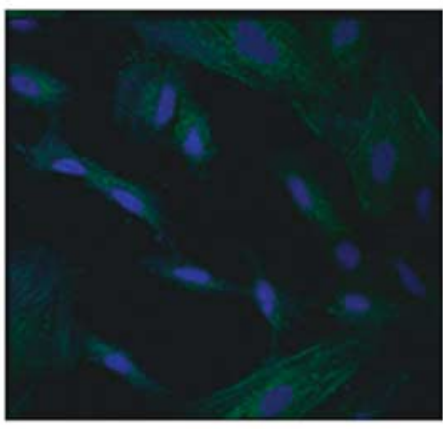

(III)-b

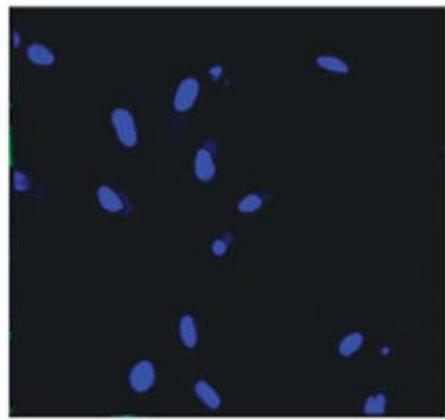

(III)-C

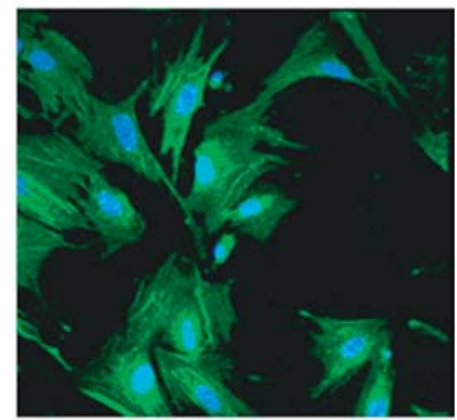

(IV)-b

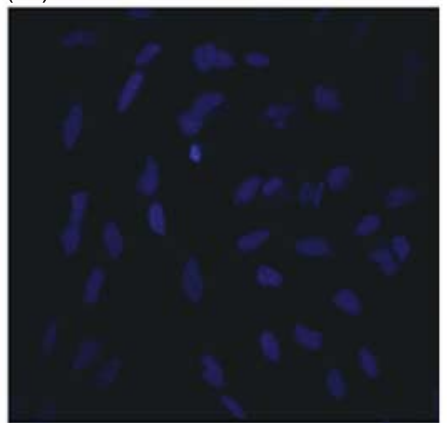

(IV)-c

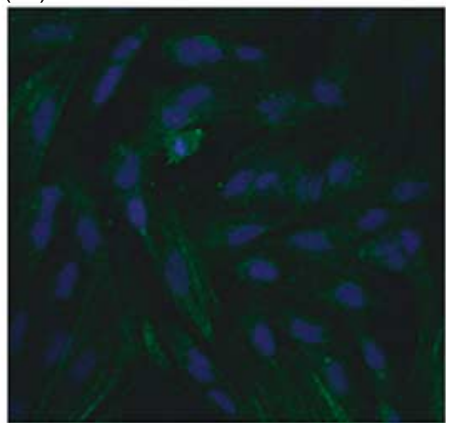

Journal of Endocrinology (2007) 193, 393-404

(I)-C

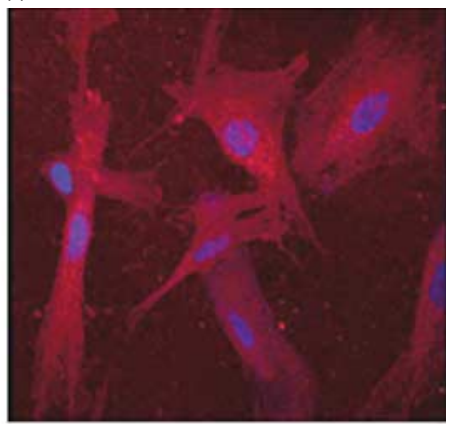




\section{I - A Control}

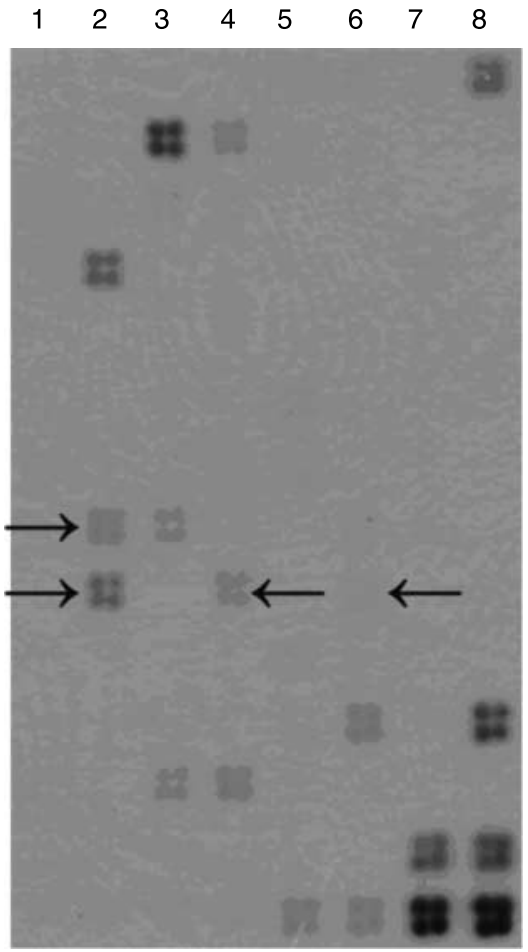

II - A $10 \mu \mathrm{M}$ ATP

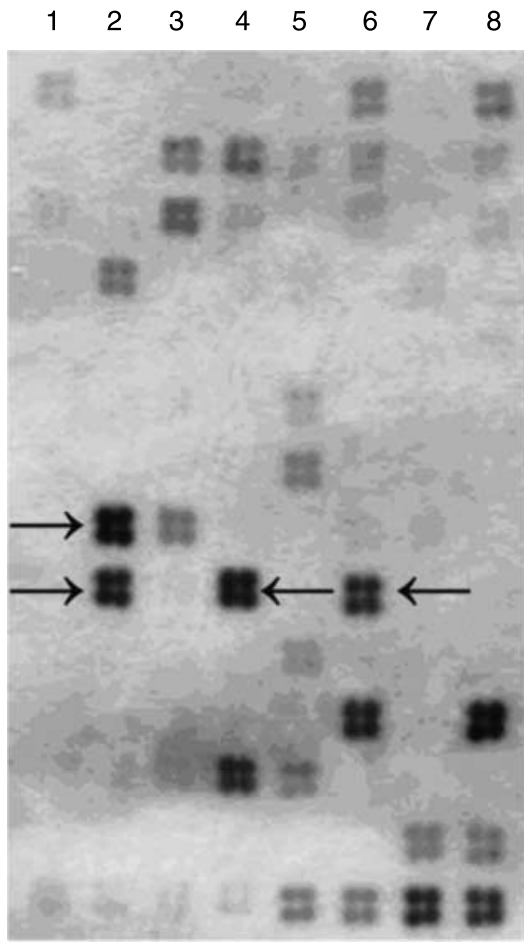

I - B $10 \mu \mathrm{M}$ ATP

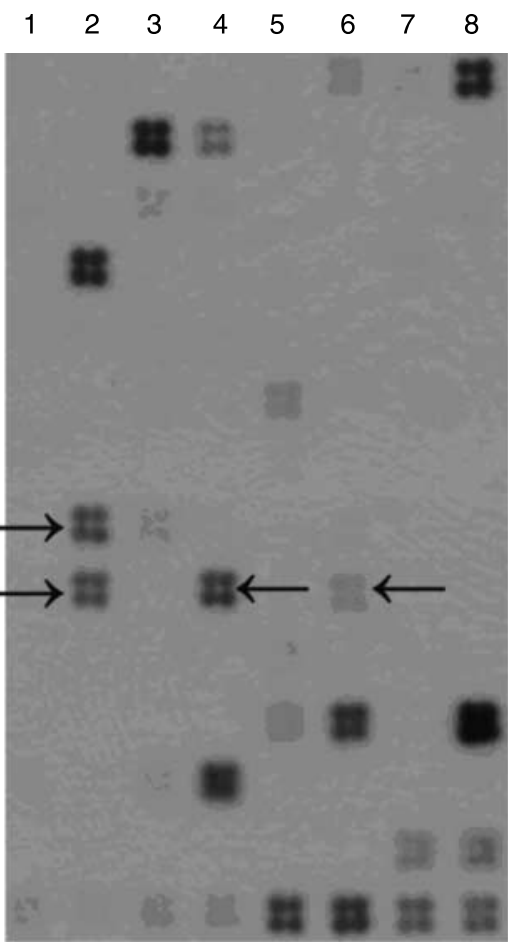

\section{II - B PD98059+10 $\mu$ M ATP}

$\begin{array}{llllllll}1 & 2 & 3 & 4 & 5 & 6 & 7 & 8\end{array}$

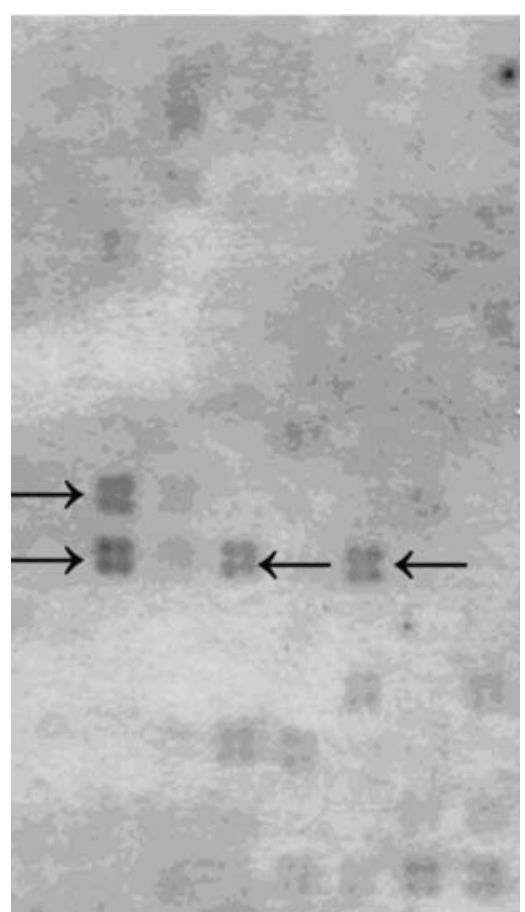


A MMP-2
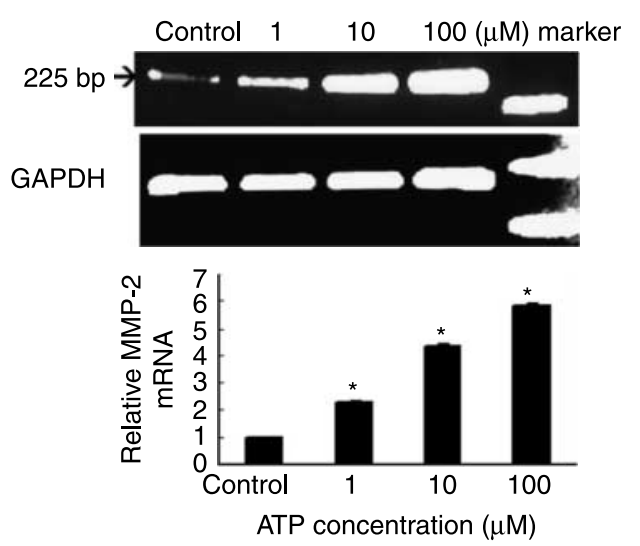

C MMP-10
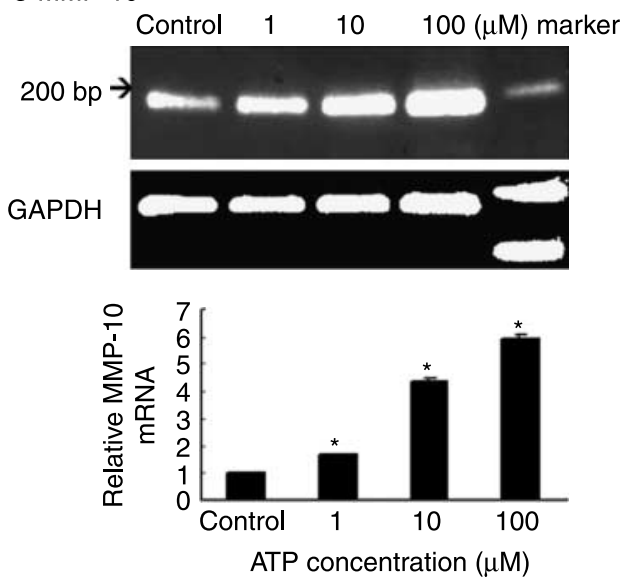

B MMP-3
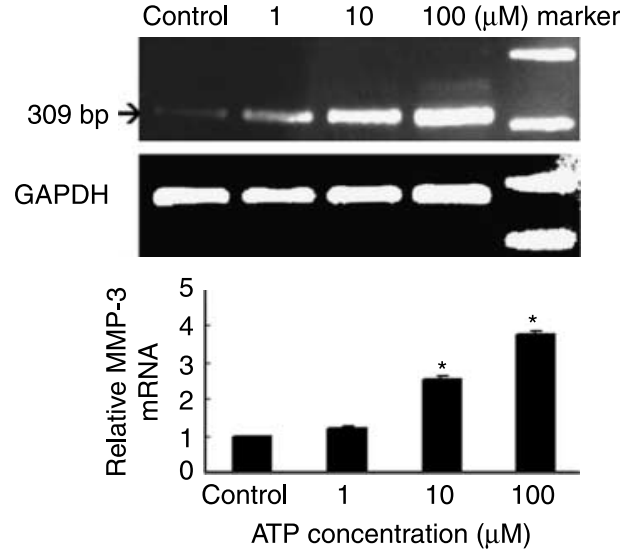

D MMP-24
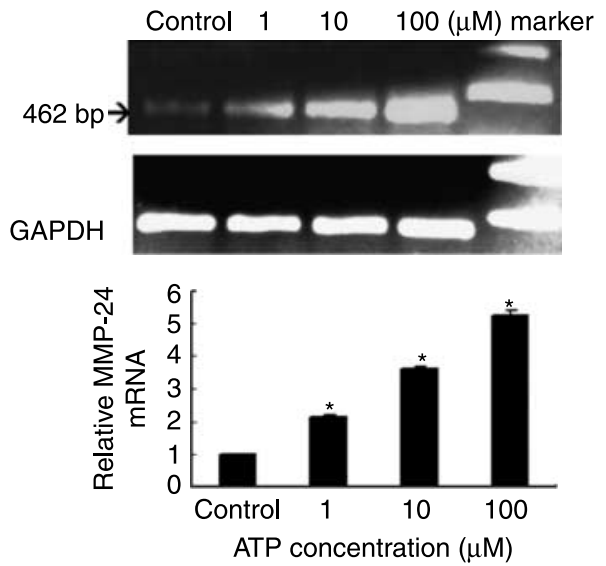

Figure 6 The effect of ATP on expression of MMP-2, -3, -10, and -24 in hESCs. Human ESCs were treated with increasing concentrations of ATP $(0,1 \mu \mathrm{M}, 10 \mu \mathrm{M}$ or $100 \mu \mathrm{M})$ for $24 \mathrm{~h}$ as described in Materials and Methods. (A) MMP-2, 225 bp, (B) MMP-3, 309 bp, (C) MMP-10, 200 bp, and (D) MMP-24, 462 bp, were separated in 3\% agarose gels, independently. The data are shown as the relative ratio to basal levels. Values are presented as the mean \pm S.E.M. of three different patients. Differences were considered significant at $* P<0 \cdot 05$.

ERK1/2, hESCs were treated with $10 \mu \mathrm{M}$ ATP for $10 \mathrm{~min}$. Once activated, phosphorylated ERK1/2 were translocated into the nuclei, and were detected by a monoclonal antibody against phosphorylated ERK1/2 (Fig. 4III-a). Figure 4IV-a demonstrates that, in the presence of PD98059, the effect of ATP on ERK1/2 translocation was completely blocked. A faint fluorescent staining revealed the distribution of phosphorylated ERK1/2 in the cytoplasm. The nuclear translocation of phosphorylated ERK1/2 was not significant when compared with the cells in Fig. 4II. The nuclei of hESCs in the present study were stained with TOTO-3 iodide and emitted blue fluorescence (Fig. 4I-b-IV-b).

\section{Gene array analysis}

Total RNA extracted from hESCs incubated in the absence or presence of $10 \mu \mathrm{M}$ ATP for $24 \mathrm{~h}$, was converted to cDNA. Superarray analysis for 96 genes related to human ECM and adhesion molecules revealed that the expression of MMP-2 (spots 2i), MMP-3 (spots 6i), MMP-10 (spots 2h), and MMP-24 (spots 4i) was increased (Fig 5-I-A and I-B). The relative abundance of $\mathrm{MMP}-2$ in the ATP-treated group was 3.5-fold greater than the control group when comparing their signal intensities to the signals derived from GAPDH from three different patients. In the presence of ATP, the expression of MMP-3 was increased by $3 \cdot 6$-fold,

Figure 5 Gene array of human extracellular matrix and adhesion molecules described in Materials and Methods. I-(A) Control group. I-(B) Human ESCs were treated with $10 \mu \mathrm{M}$ ATP for $24 \mathrm{~h}$. After hybridization, the membrane was incubated with alkaline phosphatase-conjugated streptavidin, and the signal was visualized with CDPStar, a chemiluminescent substrate, and exposed to X-ray film (2h, MMP-10; $2 i, \mathrm{MMP}-2$; $4 i$, MMP-24; 6i, MMP-3; $7 m$ and 8m, GAPDH). As shown in II-(A) Human ESCs were treated with $10 \mu \mathrm{M}$ ATP for 24 h. II-(B) Human ESCs were pretreated with PD98059 for 30 min prior to $10 \mu \mathrm{M}$ ATP exposure. The data are shown as the relative ratio to GAPDH levels. Values are presented as the mean \pm s.E.M. of three different patients. 
MMP-10 by $4 \cdot 2$-fold, and MMP-24 by $3 \cdot 6$-fold. To examine the direct effect of MMPs in gene expression, hESCs were pretreated with PD98059 for $30 \mathrm{~min}$ prior to $10 \mu \mathrm{M}$ ATP exposure, and the mRNA was extracted. As shown in Fig. 5-II-A and II-B, the effects of ATP on the expression of MMP-2, $-3,-10$, and -24 was significantly downregulated in the presence of PD98059.

\section{Effect of ATP on MMP-2, -3, -10, and -24 expressions}

To demonstrate the ability of ATP in regulating $M M P-2,-3$, 10 , and -24 genes, hESCs were treated with increasing concentrations $(0,1 \mu \mathrm{M}, 10 \mu \mathrm{M}$, or $100 \mu \mathrm{M})$ of ATP for $24 \mathrm{~h}$. As shown in Fig. 6A, ATP upregulated the level of expression of MMP-2 mRNA in a dose-dependent manner. A significant effect was observed at $1 \mu \mathrm{M}$ ATP, with a maximum effect noted at $100 \mu \mathrm{M}$. The relative abundance of MMP-2 in the ATP-treated group was $2 \cdot 2$-fold, $4 \cdot 4$-fold, and 5.8-fold greater than the control level. As shown in Fig. 6B, ATP upregulated the level of expression of MMP-3 mRNA in a dose-dependent manner. A significant effect was observed at $10 \mu \mathrm{M}$ ATP, with a maximum effect noted at $100 \mu \mathrm{M}$. The relative abundance of $\mathrm{MMP}-3$ in the ATP-treated group was 1.2-fold, $2 \cdot 6$-fold, and 3.7-fold greater than in the control group. As shown in Fig. 6C, ATP upregulated the level of expression of MMP-10 mRNA in a dose-dependent manner. A significant effect was observed at $1 \mu \mathrm{M}$ ATP, with a maximum effect noted at $100 \mu \mathrm{M}$. The relative abundance of MMP-10 in the ATP-treated group was 1.7-fold, 4.3-fold, and 5.9-fold greater than the control level. As shown in Fig. 6D, ATP upregulated the level of expression of MMP-24 mRNA in a dose-dependent manner. A significant effect was observed at $1 \mu \mathrm{M}$ ATP, with a maximum effect noted at $100 \mu \mathrm{M}$. The relative abundance of MMP-24 in the ATPtreated group was $2 \cdot 1$-fold, $3 \cdot 6$-fold, and $5 \cdot 2$-fold greater than in the control group.

\section{Discussion}

These results demonstrate for the first time that $\mathrm{P}_{2 \mathrm{U}} / \mathrm{P} 2 \mathrm{Y}_{2}$ receptor mRNA is expressed in hESCs, and that ATP is able to activate ERK1/2, induce the nuclear translocation of phosphorylated ERKs, and increase the expression of MMP$2,-3,-10$, and -24 in hESCs.

Purinergic receptors have been classified as P1 and P2 receptors. Pharmacological study demonstrated that $\mathrm{P} 1$ receptors have a high affinity for extracellular adenosine (Adenosine $>$ AMP $>$ ADP $>$ ATP), whereas $\mathrm{P} 2$ receptors have a high affinity for ATP (ATP $>$ ADP $>$ AMP $>$ adenosine). P2 purinergic receptors, $\mathrm{P} 2 \mathrm{X}_{1-7}, \mathrm{P}_{1,2,4,6,11,12,13,14}$ have been identified in molecular cloning studies (Gordon 1986, Burnstock \& Knight 2004, Burnstock 2006), and the $\mathrm{P}_{2 \mathrm{U}} / \mathrm{P} 2 \mathrm{Y}_{2}$ purinergic receptor has an equal or higher response to UTP than to ATP. The demonstration of the $\mathrm{P}_{2 \mathrm{U}} / \mathrm{P} 2 \mathrm{Y}_{2}$ purinergic receptor in hESCs implies that ATP may play a role in coordinating reproductive functions, such as the menstrual cycle and embryo implantation.

MAP kinases have been identified and they play important roles in the reproductive system (Zhang et al. 2002). The MAP kinases have been implicated in the regulation of cell growth and differentiation (Fanger 1999). MAP kinases are classified into three subfamilies: a) ERKs (extracellular signal-regulated kinases), including ERK1 and ERK2, b) SAPKs (stressactivated protein kinases), also called c-jun N-terminus kinases (JNKs), and c) p38 kinase (Tai et al. 2001a). The first MAPKs to be cloned were MAPK/ERK 1 and 2. They are phosphorylated and activated by MEKs (Boulton et al. 1991). Our results demonstrated that ATP is able to activate ERK1/2 in a dose- and time-dependent manner. Additionally, we demonstrated that ATP is capable of inducing the translocation of phosphorylated ERK1/2 from the cytoplasm to the nucleus in hESCs. The current study further examined the intracellular functioning of activated ERK1/2 in hESCs.

Extracellular ATP binds to a purinergic receptor, which belongs to one of the G-protein-coupled receptors (GPCRs). The GPCRs are used to control the activity of MAP kinases. ERK activation occurring via the GPCR/PKC pathway and EGF receptor transactivation lead to the nuclear translocation of the kinases and stimulate cell proliferation (Brunet et al. 1999, Luttrell 2002). When activated, ERKs phosphorylate a variety of substrates in the nucleus, including transcription factors and gene transcription, which have been implicated in the control of cell proliferation, differentiation and gene expression (Brunet et al. 1999). It is believed that the nucleus is also a significant site for mitogenic signal termination by the nuclear sequestration of $\mathrm{p} 42 / \mathrm{p} 44$ MAPKs away from their cytoplasmic activator, MEK, and dephosphorylation by certain nuclear phosphatases (Volmat et al. 2001). In the present study, the MAP kinase assay demonstrated that ERK1/2 activated by extracellular ATP are functional by phosphorylating the potential intranuclear substrate Elk-1. Ten micromolar ATP-induced nuclear translocation of activated ERK1/2. Phosphorylated ERK1/2 play a major role in converting mitogenic stimuli into nuclear responses. We hereby showed that the effect of ATP on ERK1/2 translocation was blocked in the presence of PD98059. This suggests that the MEK activity is essential to maintain phospho-ERK1/2 accumulated in the nucleus. Previously, we demonstrated that ATP was able to activate nuclear translocation of ERK1/2 and the induction of egr-1 and c-raf-1 expression in human granulosa-luteal cells (hGLCs; Tai et al. 2004).

MMPs are synthesized by connective tissue cells residing in the stroma of reproductive organ. Stroma can promote epithelial development or differentiation in the female reproductive tract (Hulboy et al. 1997). It has been reported that the expression of MMP-2, MMP-3, and MMP-10 has been identified in hESCs during the menstrual cycle (Henriet et al. 2002). In the present study, we examined the effect of ATP on 96 genes associated with members of human ECM and adhesion molecules. These functional gene groupings 
include cell adhesion molecules, ECM proteins, proteases, and protease inhibitors. $M M P$ genes include MMP-1 (collagenase-1), MMP-2 (gelatinase A), MMP-3 (stromelysin-1), MMP-7 (matrilysin), MMP-8 (neutrophil collagenase), MMP-9 (gelatinase B), MMP-10 (stromelysin-2), MMP-11 (stromelysin-3), MMP-12 (macrophage elastase), MMP-13 (collagenase-3), MMP-14 (MT1-MMP), MMP-15 (MT2-MMP), MMP-16 (MT3-MMP), MMP-17 (MT4MMP), MMP-20 (enamelysin), MMP-24 (MT5-MMP), and MMP-26. Among these genes, the expression of $M M P-2$, $M M P-3, M M P-10$, and $M M P-24$ genes were elevated significantly (Fig. 5-I, -II). In addition, the effects of ATP on the expression of $M M P-2, M M P-3, M M P-10$, and $M M P-$ 24 genes were confirmed in a dose-dependent study (Fig. 6 A-D) using semiquantitative RT-PCR.

MMP-2 (gelatinase A) forms the group of gelatinases that bind to and further degrade collagen denatured after initial cleavage by collagenase. In human decidual stromal cells, GnRH was capable of increasing MMP-2 and MMP-9 mRNA levels in a dose-dependent manner (Chou et al. 2003). It has been reported that MMP-2 may be involved in the regression of the right Müllerian duct in female chicken embryos (Ha et al. 2004).

MMP-3 (stromelysin 1) belongs to the group of stromelysins that degrade many components of the basement membranes and the protein core of proteoglycans. In general, MMP-3 has a proteolytic efficiency higher than that of MMP-10. In baboon endometrium, expression of stromal MMP-3 and epithelial MMP-7 increased during early menses showing that differential regulation of MMP-3 and MMP-7 is specific to cell type and stage of the menstrual cycle (Cox et al. 2000). It has been reported that early embryo-endometrial signaling modulates the regulation of MMP-3 in human stromal cell culture after progesterone stimulation (Lahav-Baratz et al. 2004).

MMP-10 (stromelysin 2) belongs to the group of stromelysins that degrade many components of the basement membranes and the protein core of proteoglycans. It has been reported that MMP-10 was found overexpressed in invasive human cervical cancer biopsies (Vazquez-Ortiz et al. 2005).

MMP-24 (MT5-MMP) is a member of the membraneassociated MMPs that are capable of activating proMMP-2. It has been reported that all six MT-MMPs were expressed in endometrium cells in a cycle-dependent pattern and the vascular expression of MT2-, MT3-, and MT4-MMP correlated with angiogenic events in the cycle (Plaisier et al. 2006). In this study, we demonstrate that ATP induced $\mathrm{P}_{2 \mathrm{U}} / \mathrm{P} 2 \mathrm{Y}_{2}$ receptor leading to the expression of MMP-2, MMP-3, MMP-10, and MMP-24 in hESCs.

We reported previously the effects of extracellular ATP on MAPKs and gene expression in hGLCs (Tai et al. 2001b, 2004). When compared with the present study, we found that ATP exerts different responses in various cells of the female reproductive system. In hGLCs, a significant effect of ATP on ERK1/2 activation was observed at $1 \mu \mathrm{M}$, with a maximum effect noted at $10 \mu \mathrm{M}$, and there was no statistical difference between cells treated with 10 and $100 \mu \mathrm{M}$ ATP. In a timedependent study, ATP was capable of rapidly inducing ERK1/2 activity. A significant effect was seen within $5 \mathrm{~min}$ after treatment, and the maximal effect was noted at the $5 \mathrm{~min}$ time-point. In contrast, no effect of ATP on ERK1/2 activation was observed at $1 \mu \mathrm{M}$ in the hESCs. A significant effect of ATP on ERK1/2 activation was observed at $10 \mu \mathrm{M}$. Additionally, a significant effect was seen within $5 \mathrm{~min}$ after treatment with $10 \mu \mathrm{M}$ ATP, and the maximal effect was noted at the 10 min time-point. ATP induced nuclear translocation of phospho-ERK1/2 after treatment for $5 \mathrm{~min}$ in hGLCs (Tai et al. 2004). On the other hand, ATP induced nuclear translocation of phospho-ERK1/2 was seen after treatment for $10 \mathrm{~min}$ in hESCs.

To our knowledge, this is the first demonstration of ATPinduced nuclear translocation of phospho-ERK1/2 and upregulation of the expression of MMP-2, -3, -10, and -24 genes in hESCs. These results support the notion that the ERK1/2 signaling pathway and MMP family play important roles in mediating ATP action in the human reproductive system.

\section{Acknowledgements}

We would like to thank the Department of Obstetrics and Gynecology, Taipei Medical University Hospital for providing human endometrium. This study was supported by the National Science Council (NSC93-2314-B-038-028) and Mackay Memorial Hospital (93MMH-TMU-01), Taipei, Taiwan. The authors declare that there is no conflict of interest that would prejudice the impartiality of this scientific work.

\section{References}

Berridge MJ 1984 Inositol trisphosphate and diacylglcerol as second messengers. Biochemical Journal 220 345-360.

Boulton TG, Nye SH, Robbins DJ, Ip NY, Radziejewska E, Morgenbesser SD, DePinho RA, Panayatatos N, Cobb MH \& Yancopoulos GD 1991 ERKs: a family of protein-serine/threonine kinases that are activated and tyrosine phosphorylated in response to insulin and NGF. Cell 65 663-675.

Brunet A \& Pouyssegur J 1997 Mammalian MAP kinase modules: how to transduce specific signals. Essays in Biochemistry 32 1-16.

Brunet A, Roux D, Lenormand P, Dowd S, Keyse S \& Pouyssegur J 1999 Nuclear translocation of $\mathrm{p} 42 / \mathrm{p} 44$ mitogen-activated protein kinase is required for growth factor-induced gene expression and cell cycle entry. EMBO Journal 18 664-674.

Burnstock G 2006 Purinergic signaling. British Journal of Pharmacology 147 172-181.

Burnstock G \& Knight GE 2004 Cellular distribution and functions of P2 receptor subtypes in different systems. International Review of Cytology $\mathbf{2 4 0}$ 301-304.

Chou CS, Tai CJ, MacCalman CD \& Leung PCK 2003 Dose-dependent effects of gonadotropin-releasing hormone on matrix metalloproteinase MMP-2, and MMP-9 and tissue specific inhibitor of metalloproteinase-1 messenger ribonucleic acid levels in human decidual stromal cells in vitro. Journal of Clinical Endocrinology and Metabolism 88 680-688. 
Cox KE, Sharpe-Timms KL, Kamiya N, Saraf M, Donnelly KM \& Fazleabas AT 2000 Differential regulation of stromelysin-1 (matrix metalloproteinases-3) and matrilysin (matrix metalloproteinases-7) in baboon endometrium. Journal of the Society for Gynecologic Investigation 7 242-248.

Dong JC, Dong H, Campana A \& Bischof P 2002 Matrix metalloproteinases and their specific tissue inhibitors in menstruation. Reproduction 123 621-631.

Fanger GR 1999 Regulation of the MAPK family members: role of subcellular localization and architectural organization. Histology and Histopathology 14 887-894.

Gargett CE, Lederman F, Heryanto B, Gambino LS \& Rogers PA 2001 Focal vascular endothelial growth factor correlates with angiogenesis in human endometrium. Role of intravascular neutrophils. Human Reproduction $\mathbf{1 6}$ 1065-1075.

Goffin F, Munaut C, Frankenne F, d'Hauterive SP, Béliard A, Fridman V, Nervo P, Colige A \& Foidart JM 2003 Expression pattern of metalloproteinases and tissue inhibitors of matrix metalloproteinases in cycling human endometrium. Biology of Reproduction 69 976-984.

Gordon JL 1986 Exracellular ATP: effects, sources and fate. Biochemical Journal 233 309-319.

Ha Y, Tsukada A, Saito N \& Shimada K 2004 Changes in mRNA expression of MMP-2 in the Müllerian duct of chicken embryo. General and Comparative Endocrinology 139 131-136.

Henriet P, Cornet PB, Lemoine P, Galant C, Singer CF, Courtoy PJ, Eeckhout Y \& Marbaix E 2002 Circulating ovarian steroids and endometrial matrix metalloproteinases (MMPs). Annals of the New York Academy of Sciences $\mathbf{9 5 5}$ $119-138$.

Hulboy DL, Rudolph LA \& Matrisian LM 1997 Matrix metalloproteinases as mediators of reproductive function. Molecular Human Reproduction 3 27-45.

Jung M, Römer A, Keyszer G, Lein M, Kristiansen G, Schnorr D, Loening SA \& Jung K 2003 mRNA expression of the five membrane-type matrix metalloproteinases MT1-MT5 in human prostatic cell lines and their down-regulation in human malignant prostatic tissue. Prostate 55 89-98

Kim JH, Kim TH, Jang JW, Jang YJ, Lee KH \& Lee ST 2001 Analysis of matrix metalloproteinase mRNAs expressed in hepatocellular carcinoma cell lines. Molecules and Cells 12 32-40.

Kim-Kaneyama J, Nose K \& Shibanuma M 2000 Significance of nuclear relocalization of ERK1/2 in reactivation of c-fos transcription and DNA synthesis in senescent fibroblasts. Journal of Biological Chemistry 275 20685-20692.

Laemmli UK 1970 Cleavage of structural proteins during the assembly of the head of bacteriophage T4. Nature 227 680-685.

Lahav-Baratz S, Shiloh H, Koifman M, Kraiem Z, Wiener-Megnazi Z, Ishai D \& Dirnfeld M 2004 Early embryo-endometrial signaling modulates the regulation of matrix metalloproteinase-3. Fertility and Sterility 82 1029-1035.

Luttrell LM 2002 Activation and targeting of mitogen-activated protein kinases by G-protein-coupled receptors. Canadian Journal of Physiology and Pharmacology 80 375-382.

el-Moatassim C, Dornand J \& Mani JC 1992 Extracellular ATP and cell signalling. Biochimica et Biophysica Acta 1134 31-45.

Owman C, Rosenbren E \& Sjoberg NO 1967 Adrenergic innervation of the human female reproductive organs: a histochemical and chemical investigation. Obstetrics and Gynecology 30 763-773.

Parr CE, Sullivan DM, Paradiso AM, Lazarowski ER, Burch LH, Olsen JC, Erb L, Weisman GA, Boucher RC \& Turner JT 1994 Cloning and expression of a human $\mathrm{P} 2 \mathrm{U}$ nucleotide receptor, a target for cystic fibrosis pharmacology. PNAS 91 3275-3279.
Plaisier M, Koolwijk P, Hanemaaijer R, Verwey RA, van der Weiden RM, Risse EK, Jungerius C, Helmerhorst FM \& van Hinsbergh VW 2006 Membrane-type matrix metalloproteinases and vascularization in human endometrium during the menstrual cycle. Molecular Human Reproduction 12 $11-18$.

Shiokawa S, Yoshimura Y, Nagamatsu S, Sawa H, Hanashi H, Oda T, Katsumata Y, Koyama N \& Nakamura Y 1996 Expression of $\beta-1$ integrins in human endometrial stromal and decidual cells. Journal of Clinical Endocrinology and Metabolism 81 1533-1540.

Tai CJ, Kang SK, Cheng KW, Choi KC, Nathwani PS \& Leung PCK 2000 Expression and regulation of $\mathrm{P} 2 \mathrm{U}$-purinergic receptor in human granulosaluteal cells. Journal of Clinical Endocrinology and Metabolism 85 1591-1597.

Tai CJ, Kang SK, Choi KC, Tzeng CR \& Leung CR 2001 a Antigonadotropic action of adenosine triphosphate in human granulosa-luteal cells: involvement of protein kinase Calpha. Journal of Clinical Endocrinology and Metabolism 86 3237-3242.

Tai CJ, Kang SK, Tzeng CR \& Leung PCK $2001 b$ Adenosine triphosphate activates mitogen-activated protein kinase in human granulosa-luteal cells. Endocrinology 142 1554-1560.

Tai CJ, Chang SJ, Leung PCK \& Tzeng CR 2004 Adenosine 5'-triphosphate activates nuclear translocation of mitogen-activated protein kinases leading to the induction of early growth response 1 and raf expression in human granulosa-luteal cells. Journal of Clinical Endocrinology and Metabolism 89 5189-5195.

Tokunaga K, Nakamura Y, Sakata K, Fujimori K, Ohkubo M, Sawada K \& Sakiyama S 1987 Enhanced expression of a glyceraldehyde-3phosphate dehydrogenase gene in human lung cancers. Cancer Research 47 5616-5619.

Towbin H, Staehelin T \& Gordon J 1979 Elcetrophoretic transfer of proteins from polyacrylamide gels to nitrocellulose sheets: procedure and some applications. PNAS 76 4350-4354.

Vazquez-Ortiz G, Ciudad CJ, Pina P, Vazquez K, Hidalgo A, Alatorre B, Garcia JA, Salamanca F, Peralta-Rodriguez R, Rangel A et al. 2005 Gene identification by cDNA Arrays in HPV-positive cervical cancer. Archives of Medical Research 36 448-458.

Visse R \& Nagase H 2003 Matrix metalloproteinases and tissue inhibitors of metalloproteinases: structure, function, and biochemistry. Circulation Research 92 827-839.

Volmat V, Camps M, Arkinstall S, Pouyssegur J \& Lenormand P 2001 The nucleus, a site for signal termination by sequestration and inactivation of $\mathrm{p} 42 / \mathrm{p} 44$ MAP kinases. Journal of Cell Science 114 3433-3443.

Willson JR, Ledger WJ \& Andros GJ 1965 The effect of an intrauterine contraceptive device on the histologic pattern of the endometrium. American Journal of Obstetrics and Gynecology 93 802-809.

Zhang Q, Liu SH, Erikson M, Lewis M \& Unemori E 2002 Relaxin activates the MAP kinase pathway in human endometrial stromal cells. Journal of Cellular Biochemistry 85 536-544.

Received in final form 12 March 2007

Accepted 17 March 2007

Made available online as an Accepted Preprint

21 March 2007 